\title{
The Convergence of Human and Citizenship Rights in the Globalization Era
}

\author{
Amir Biparva $^{1} \&$ Sayed Qasem Zamani ${ }^{2}$ \\ ${ }^{1} \mathrm{PhD}$ student of public international law, Imam Reza international University, Mashhad, Iran \\ ${ }^{2}$ Faculty board member of Allameh Tabatabaee University, Tehran, Iran \\ Correspondence: Sayed Qasem Zamani, Faculty board member of Allameh Tabatabaee University, Tehran, Iran. \\ E-mail: drghzamani@gmail.com
}

Received: April 27, 2016
doi:10.5539/mas.v10n9p94

Accepted: May 11, 2016

Online Published: June 7, 2016

URL: http://dx.doi.org/10.5539/mas.v10n9p94

\begin{abstract}
Human and citizenship rights, the former refers to the individual for being a human and the latter to citizens of statesfor being members of a political community, have their own historical, social and political foundations. Therefore, any analysis about their relations should bring historical, social and legal foundations into consideration. While the content of citizenship rights can be analyzed in the context of human rights and in fact they origin from them, their relationship should be characterized based on their substantive and procedural aspects. One cannot claim the overlapping or inconsistency of these two rights just by conducting a shallow analysis. Particularly in the era of globalization and expansion of international communication, these rights have been the centerpiece of all global issues. Thus, paying attention to the relationships between these rights in both national and international levels is very important.
\end{abstract}

Keywords: human rights, citizenship rights, nationality, government, society

\section{Introduction}

Human and citizenship rights are common concepts which are frequently used in the modern world. Regardless of their academic origin and frequent usage in law and sociology faculties, they are very functional among the public opinion, states and international organizations. Due to the necessary application of these familiar terms their signification should be brought into consideration in the first place. Respecting human rights and preparing the groundwork for their implementation are inevitably necessary for safeguarding the human integrity and dignity. Here, universal human rights supported by the international community should be highlighted. They are a set of rights which the individual has from his/her birth and stated are obliged to respect them.

The syntactic relationship between "human" and "rights", in one hand, signifies the main elements of human existence, i.e. his body and mind, such as right to life, right to petition, freedom of thought conscience and religion and right to vote. These kinds of rights whose aims are to preserve the moral and bodily integrity of individuals and their liberty and security are sometimes called "freedom rights". They define the limits of human whishes and freedom which the state must respect and does not violate them unless it wants to preserve those rights. They are called civil-political rights. On the other hand, this relationship refers to rights related to necessary conditions of every individual's life which are beyond main elements of human existence and put certain obligations on the society and government. These rights include right to employment, social security, right to access to the minimum means of livelihood, right to health, right to education, etc. These kinds of rights are called "participatory rights" and entail providing necessary means for human prosperity in the society. Therefore, the content of human rights is very diverse. It is completely logical that nothing can prevent the daily expansion of these rights according to changes made in social conditions. In this way, new human rights such as right to self-determination, right to development, right to peace and right to a healthy and happy life can be introduced (Sayed Fattemi, 2011, pp. 19-20). A set of rights are necessary for enjoying a perfect life. Providing those rights completes the human life. An individual person must enjoy the right to life from his birth time till his natural death. He must also enjoy right to access information, freedom of speech, mindand participation in political and civil activities. On the other hand, that person must enjoy right to access to the minimum means of livelihood, right to health, right to food, right to employment, right to education, right to self-determination and right to peace and security. It is through enjoying these rights that the human being can prosper. 
Citizenship rights are among the concepts which entail the rights and freedom of a nation and every person who is a member of that particular nation enjoy them. Although family, society, government and any other political entity are consisted of individuals, a time comes when not only do they challenge the individuality of an individual but erase him and his features. It is when the individual's rights become important for him and he is compelled to seek his freedom in the world in which he has been abandoned. He is compelled to manifest, through his will and reactions, that he exists, his biological and psychological needs must be accepted and that contributes to his social and political destination. When a person becomes aware of his own rights and the society yields to this awareness, his right to have a civilized life will be realized. A democratic state pays attention to these rights and manifests them in its constitution. The government reacts toany thread to these rights and protects the rights and freedom of its citizens. Citizens, also, accept respecting the freedom of other citizens as their own obligations.

It is only through accepting the rights, independence, individuality of others and respecting political and social values that one can become the citizen of a society. The citizen of a society is an individual; it is through valuing the rights of that person which citizenship rights can be understood as a reality. The right of an individual makes the basis for citizenship rights and they are demonstrated through it. Citizenship rights are specified rights which belong to the members of a specific society because of their membership. Citizenship rights and their implementation differ among different societies (lija, 2011, p. 16). Based on the above mentioned matters, citizenship rights should be considered as a set of rights and obligations which every individual person enjoys just because of his membership in a political state, in its broad sense. According to the above mentioned explanations about human and citizenship rights, the relationship between these two concepts should be scrutinized in terms of their similarities and differences. The relationship between these two concepts is important for illustrating each of them and stating the subject matter. Therefore, this relationship must be analyzed in historical, legal and social contexts. In this analysis, different kinds of each right and the kinds of concepts it belongs to should be taken into consideration. Considering these explanations, this question arises that whether human and citizenship rights are connected issues or separated ones? The answer should be considered in terms of historical origins and social statute of these rights and their position in the legal system of every society. This can illustrate the relationship between human and citizenship rights in a logical context and show that how citizenship rights are connected with human rights and in what aspects they are covered by them.

Both human and citizenship rights are familiar concepts in political and legal literature. They are so important that have gone beyond theoretical debates and become omnidirectional concepts in political and practical areas for legitimizing ruling over citizens. These concepts are so important of in different political and legal areas that political powers make use of them to justify their actions in national and international levels. Media contents which directly or indirectly communicate human and citizenship rights issues illustrate this justification; few days can be found in which media do not present these issues. These all elucidate the importance of these concepts in the modern era. Hence, their relationship is very important and here it is analyzed in different aspects.

\section{Human and Citizenship Rights from Historical Point of View}

Citizenship and democracy were first brought about in ancient Greece and signified equal rights, obligations and active participation in the political arena (Lipset, 2005, p. 950). In the ancient Greece and Roman republics, the citizens had the right to participate in the society and citizenship meant belonging to a political community with shared political concerns which separate that community from ethnic and religious communities (Honohan, 2002, p. 4). For Aristotle, citizens are people who cooperate to establish order in times of chaos andlegislate to gain common good; in his point of view belonging to this society is possible through blood tie (Castles \& Seven, 2003 , p. 106). He also believes that exercise of citizenship is more important and considers it as the main pillar of humanness and claims that a person who does not participate in the society administration either a god or an animal (Falks, 2003, p. 29).

Accordingly, citizenship should be considered as the right of individuals to participate in political affairs and their obligations to follow the rules. Because of their membership in society, people have the right and obligation to participate in political affairs. This view results from close relationship between an individual and the society so that citizenship means serving the society.

The ancient Roman citizenship did not mean active citizenship or exercising political power and just entailed, according to laws, some parts of rights and obligations. However, it was all-inclusive and a kind of military and economic oligarchy appeared that prevented it from being democratic and was confined to the fair hearing (Falks, 2003, p. 32). Roman citizenship model was preserved in the medieval era. Governance, feudalism and 
non-public, hierarchical citizenship based on ownership was completely obvious. Yet, citizenship found an equalitarian basis with the advent of liberalism. At that time, states were absolute monarchies, in which every property belonged to the king (Castles, 2003, p. 125). With the establishment of sovereign state in its modern sense, after the Westphalia Treaty and Congress of Vienna, the principle of the system of balance of power was created and citizenship gained a special importance. Liberalism played a significant role in the emergence of general citizenship. In $19^{\text {th }}$ century, citizenship was defined as a set of rights and obligations which determines the relationship between nation-states and each of citizens. In fact, it shall be said that civil rights were developed in $18^{\text {th }}$ century, political rights in $19^{\text {th }}$ century and social, cultural and economic rights in $20^{\text {th }}$ century (Falahzadeh, 2003, p. 51).

The French revolution played a significant role in the development of the concept of citizenshipsince civil, anti-racism, and right to vote movements have their roots in this great revolution. With the end of the Second World War and establishment of United Nations and universal declaration of human rights, the international community accepted many concepts. Right to citizenshipis one of these concepts which the international community hasaccepted and the universal declaration of human rights has recognized itas a human right. The aim of this recognition is to help people to enjoy their citizenship rights. Citizenship has a tightly connected with nationality so that, in one hand, citizenship means entitlement to right to vote, holding political offices, equality before the law, entitlement to take advantage of different benefits and services and, on the other hand, it entails such obligations as paying tax.

From a historical point of view, one cannot determine a certain basis for the advent of human rights. The time of their emergence cannot be stated with certainty. Here, a general question arises which asks when have human rights come to existence? No certain question can be given. Some scholars believe that they date back to two thousand years before Christ while some other believe that it can merely be realized at the late $20^{\text {th }}$ century, i.e. four thousand years later (Hashemi, 2006, p. 113).

While it is true that rules relating to protecting human rights have been codified in international conventions and statutes over the past two or three centuries, it is wrong to limit these rights to this brief period of the human history. It is because the importance of these rights as human values has been into the focus of attention since many centuries ago and human beings have basic rights that are part of their essence (Narima, 1993, p. 501).

Human rights rules are based on and originated from the human dignity because human for sake of their humanness and regardless from political, geographical, racial and religious constraints enjoy them. Thus, these rules have always been existed since the very day that human beings came to this world and it has been based on them that human life has esteemed. The human dignity has been respected from distant past and it demonstrates human rights rules. For instance, the preoccupation of Hammurabi, the founder of the city-state of Babylon, was to prevent strong people from abusing weak ones through the justice; or declaration of Confucian philosopher Mang-Tzu, three centuries before the Christ, insisted that the human individual has eternal importance and the king is not so important (Jacques Morzenon, 2002, p. 21). The history of the human dignity dates back to thousands years ago. The Behistun Inscription authored by Darius the Great, the king of the Persian Empire, states that:" I am a lover of truth. I despise wrong doing. I hate that the strong oppress the weak. I also hate that the weak oppress the strong. The right action is what I want". This description was near decorative carvings in one of which the Persian king's effigy is killing a monster which is the symbol of evil. This depiction is the symbol of the principles of official religion of that time, i.e. Zoroastrianism, according to which the human life is a battle between theevil and good. Of course at the end the good will wipe out the evil.Zoroaster gave the lowest peasant such a social position that no empire could ever deprive him from it. It is also not surprising that the first declaration of human rights was carved on a clay cylinder at the time of Cyrus the Great (Sharifi Taraz Kuhi, 2014, pp. 37-38).

Human rights rules are based on the inherent human dignity and government are obliged to protect them. However, codification of these rules in recent centuries has provided mechanisms for protecting human rights so that national constitutions and legislations as well as international conventions oblige states to guarantee human rights rules. So, what should be contributed to the past two centuries is codification of rules related toobligations of states to protect human rights (Https://unchroncile.un.org/article/international-human-rightslaw-short-history).

\section{Human and Citizenship Rights from a Social Standpoint}

Human and citizenship rights are both concepts shaped in the light of the society. The foundation of these concepts has been the participation of people in the society both in geographical and global levels. The members of each society have a set of rights accepted in the context of human and citizenship rights whose foundation is social development of that society and the yield of its social life.Based on the level of development in different 
societies, various relationships come to existence whose parties are citizens of those societies. Rights and obligations of citizens are defined in the context of these relations. The history of mankind demonstrates that these relations must be regulated in different aspects and specific regulations must rule over them. For without specific regulation ruling over them, conflict of interests results in turmoil, loss of security, anarchy and violence.

As was mentioned above, human right is a kind of right which human being enjoys because of being a human. Regardless from rights and obligations which an individual enjoys because of his membership in a political, cultural or economic society, all human beings enjoy human rights. Regarding the obviousness of the humanness of human beings, human rights which originate from it are also inalienable and undeniable. Human rights should be considered as internationally recognized rights which are a part of human social life. Regardless from membership in national, ethnic, economic and religious communities, all human beings enjoy these rights. They are not subject to membership in a special community or under a specific political regime but every human being enjoy them because of his humanness.

Human and citizenship rights are both terms which gain their meaning in the context of the society and outside of it are meaningless. They are internationally recognized rights which every human being enjoys because of his membership in a national community or his humanness.

In other word, it can be said that international human rights laws are nothing but a restatement of natural rights which is compatible with the contemporary legal system; a set of rules and norms supported by ethics and public opinion and hardly can be violated (Amery, 1984, p. 14). Citizenship is not just normative but has a historical, cultural and social nature. Citizenship is related to the history of social development but human rights originate from ethic values and have a normative nature (Falahzadeh, 2003, p. 59). Citizenship is a social phenomenonin that citizenship of a citizen depends on other citizens and a person cannot participate in a community without other people. The experience of Indigenous people throughout the world is a good example. When indigenous people enjoy citizenship rights, discrimination against them by government and other citizens obstacles changes in their lives; they interfere into their political affairs and make decision instead of them (Phelan, 2001, p. 27). Social acceptance of citizenship and enjoying its rights is an important issue. Regardless from legal entitlement, citizenship depends on adoption of a person as a citizen of a society by that society. Thus, a citizen may, due to some exceptions like his membership in an ethnic or religious group, be in minority and cannot influence the society as others do.

Citizenship is a mutual relation which includes mutual rights and obligations of citizens against each other and the state whereas human rights are unidirectional relationships which pertain to the rights of individuals.

Human rights are individualistic in nature since they belong to a person because of his humanness and that person can claim their implementation individually while citizenship rights have a collective nature they refer to rights which belong to a group, community or society because of their collectivity and are implemented collectively. Right to vote andright to participate in political affairs are collectively implemented. Being of a collective nature, the aim of human rights is to protect the individual against the state. In this sense, due to the lack of a power balancebetween the individual, society and state, inalienable rights are given to the individual to protect his dignity against the state and it is obliged to protect them (Folks, 2001, p. 82).

Human and citizenship rights have an authentic relationship with social norms and their rules are in direct connection with these norms.

These rights supervise the protection of human dignity and logically originate from fundamental freedom and individual autonomy. For example, one can state universal and popular norms such as Justice, fairness and non-discrimination which are based on natural and inherent needs and despite differences in definitions and applicability are interesting concepts (Sharifi Taraz Kuhi, 2014, p. 29).

Citizenship is a relation between the individual and the state whose parties are tied to each other because of the rights and obligations. Due to enjoying this fundamental right, citizens enjoy perfect membership in their political state and hence differ from foreigners (Hywood, 2004, p. 174). Citizenship brings about the fair treatment of citizensand the state inside the society and protecting citizens outside of it. Citizenship cause entitlement so that it should be regarded as the maincharacteristic ofmembership in acommunity (Phelan, p. 14).

A relationship that connects these rights is a mutual one because it is bilateral and based on rights and obligations. In fact, citizenship means planning a social system to limit the government and social management and is more of a social nature. Membership is the main element of this system and social rights and obligatio ns like defending the country, paying tax and following rules are also important. As was early mentioned, citizens are 
not only responsible against the state they are also responsible against other citizens. Citizenship, in its broad sense, entails responsible involvement in social processes and thus refers to accepted obligations in a specific social context. In other words, citizenship as an opportunity for membership in a society has its own requirements which include a set of rights, duties and obligations (Sharifi Taraz Kuhi, 2014, p. 152).

Citizens have general and specific duties and obligations. General obligations are those which the societyimposes on them and are among the requirements of the social life. Specific obligations are those the state specifies. General obligations of citizens are against rulers, the government and other citizens. The responsibility of citizens against the governmentis to be loyal to it and obey its rules. Their responsibility against other citizens is to live in peace and security with them. Specific responsibility of citizens is against the whole government (Pufendruf, 1991, p. 175).

\section{Human and Citizenship Rights from the Legal Perspective}

Human and citizenship rights are common terms in the international law so that their derivatives are among the basic key words of its literature. As was mentioned above, these terms can be interpreted from different angles. They can also be analyzed from the legal perspective and this analysis is necessary for explaining their legal relationships. Human and citizenship rights are legal principles whose basis is to protect citizens and humanity. However, as was already mentioned, they have differences and similarities.

All human beings enjoy human rights which belong to them because of their humanness whereas citizenship rights only belong to the national of a country. These rights have three basic elements which separate them from human rights including:

1. Right to political participation;

2. Right to political protest/criticism;

3. Right to legislate (Cheria \& Edwin, available at: Http//www.openspace.org.in/citizenship).

These rights just belong to the citizens of a special country. Although these three rights do not cover all citizenship rights, due to their relationship with the nationality of individuals can separate citizenship rights from human rights. Citizenship rights which are based on these elements are also based on the nationality of individuals. Nationals of a country are citizens of that country and enjoy exclusive rights unique to its citizens and those who are not nationals of that country do not enjoy them. Citizenship empowers the national of a state to participate in governance and legislation. Citizenship allows people to supervise their leaders. It also allows them to supervise their own actions and cooperate with other citizens in an equal manner and with mutual respect (Bellamy, 2008, p. 1). All rights which are based on these principles allow people to participate, either directly or indirectly, in political affairs. Direct participation in political affairs is manifested in holding political offices; indirect participation is through participation in election and other political activities. Participation in legislation comes true throughparliamentary representationand its election. Supervision by citizens on current affairs justifies their right to protest against political issues of their society.

In addition to what can be stated about the substantive difference between human and citizenship rights, their procedural differences can also be analyzed. It should be stated that citizenship right is a bilateral relation based on right and obligations whereas human right is an omnidirectional relationship merely based on rights. Citizenship means ruling and being ruled over (Marsh, 1992, p. 153).

A relationship which presents the legal statute in human rights discourse is often an omnidirectional relation since it is of a demanding nature and individuals demand it. It is obvious that despite citizenship rights, no obligation is presented in this discourse and they seek a certain degree of freedom to guarantee the existence and moral activity of the individual (Falahzadeh, 2003, p. 59).

Article 15 of universal declaration of human rightsrecognizes the right to a nationality. The aim of this recognition is to entitle people their citizenship rights and is based on the close relation between citizenship and national. Right to self-determination should be considered as the basic idea of citizenship, i.e. citizenships seek to guaranteethe determination of each person in his own society and to specify a set of rights and benefits because of his citizenship. Then, citizenship and its pertinent rights have an authentic relationship with the nature of citizens in determining their own social, political, cultural and economic determination. Citizenship means entitlement to right to vote, holding political offices, equality before the law, entitlement to take advantage of different benefits and services and, on the other hand, it entails such obligations as paying tax. The scope of citizenship rights is limited to the territory of a nation state since membership is the main element of citizenship but human rights claim to be universal. The right side in the citizenship system is nationals or citizens of a state while in human rights system it is states and human for his humanness. Of course, it should be noted that 
non-nationality does not flaw human rights in the territory of any country. All individuals, regardless from being the national of a state or not, are entitled to human rights. Human rights are equally exercised for citizens, aliens and even stateless individuals. The Committee on Civil and Political Rights stated in his $15^{\text {th }}$ general comment that (Note) each one of the rights of the Covenant must be guaranteed without discrimination between citizens and aliens. All individuals, whether are citizens or aliens, are entitled to freedom from arbitrary detention and murder, equality before courts and jurisdictions, and freedom of thought, conscience and religion and aliens are entitled to freedom of marriage, being supported as minorities and peaceful assembly (Weissbrodt \& Meili, 2010, p. 38). Of course as was mentioned earlier, such rights as right to vote and holding political offices are unique to citizens and aliens are deprived of them. International Covenant on Economic, Social and Cultural Rights states that the states parties to this covenant should take appropriate steps to safeguard people right to work and favorable conditions of work, right to adequate standard of living, right to health, right to education and other economic, social and cultural rights regardless of their national (Weissbrodt \& Meili, 2010, p. 38).

Universal human rights are considered fundamental and absolute. Their universality means that all people, throughout the world, can enjoy them regardless of their ethnic, race and social origin; their fundamentality means that they cannot beconstrained.

Human and citizenships have many common features so that a kind of overlapping can be found between them. Many values of human and citizenship rights are common. In a society whereexplicit and implicit facilities have been provided for citizens, the human dignity of citizens, which is based on fundamental standards and basic considerations derived from common values, influences the political, legal and public order (Clark, 2000, p. 185).

States safeguard both human and citizenship rights. Human and citizenship rights overlap each other in many stated aspects. Concepts of citizenship rights can be found in legal literature. In fact, it can be said that civil and political rights connect these two kinds of rights since civil rights safeguard the physical and moral integrity of the person and political rights prepare him for an active participation in the society. For example, all citizens and aliens have the right to access the justice before the European Court if they claim that their rights have been violated (Nash, 2010, p. 10).

Giving this overlapping, citizenship rights are, in one hand, based on the national because citizens are in first place human beings and then citizen of a certain country and, on the other hand, they are based on human rights and should be considered as a part of them.

\section{Conclusion}

The relationship between human and citizenship rights must be analyzed in historical, social and legal contexts. These contexts illustrate this relationship both in its substantive and procedural aspects.

From the historical perspective, human rights begin from the very day that the human being comes into existence, however, citizenship rights, which have a direct, bilateral relationship with the state, begins since the advent of first sovereign states. From social point of view, human rights are obligations on part of stateswhich they should provide through their positive and negative obligations whereas citizenship rights are a bilateral relation based on both right and obligation. In one hand, states are obliged to implement these rights and should provide opportunities for citizenship rights like political participation and election. On the other hand, citizens have a set of obligation toward the state which paying tax is one of them. From the legal standpoint, human rights belong to all human beings but citizenship rights entitlement is subject to membership in a special political state so that entitlement of these rights shows the membership if the individual in a political state called a country. In terms of procedural relationship between human and citizenship rights it must be said that they are both common in being a set of rights but the obligation side of citizenship rights separate it from human rights so they overlap each other but each of them has its own applicability. Therefore, it is a general-specific relationship.

Human and citizenship rights are both based on the human dignity so that rights such as right to political participation and right to vote are just entitled to national of a specific state and are based on political and civil freedom. So, according to the content of the relationship between human and citizenship rights, it should be considered an absolute-specific relation. Therefore, all citizenship rights originate from human rights. Basically, all citizenship rights root from human rightseven citizenship itself is a part of human rights.

\section{References}

Amery, J. (1984). Private International Law. Tehran, Agah Publication.

Bellamy, R. (2008). Citizenship a very short introduction. New York, Oxford University Press. 
Cherra \& Edwin (2014, July 15). Citizenship and humanrights. Retrieved from $\mathrm{http} / / \mathrm{www}$. openspace.org.in/citizenship

Clark, R. (2000). How international human rights law affects domestic law in human rights: new prespectives, new realities. London, lynnerienner publishers.

Falazadeh, A. M. (2007). Relationship between human and citizenship rights. The Judiciary Law Journal, 58.

Falks, K. (2003). Citizenship (T. Delforuz, Trans.). Gazal Publication.

Hashemi, S. M. (2008). Human Rights and Fundamental Freedoms. Tehran, Mizan Publication.

Honohan, I. (2002). Civic republicanism. Routledge, London.

Hywood, A. K. (2004). Concept in politics; paly rav publication.

Jacques, M. (2002). Human Rights (Naqibzadeh, Trans.). Law School Publication of Tehran University.

Lija, V. I. (2011, Decmber). An analisys of the concept of citizenship: Legal, political and social demminisions, masterthesis, university of hellsinki.

Marshal, T. H. (1992). Citizenship and social class. London, plutopress.

Nariman, F. (1993). The universality of human rights. The review of international commission of jurists, 50.

Nash, K. (2009). Between citizenship and humanrights. Sociology, 43.

Phelan, S. (2001). Sexual strangers: gays, lesbians and delimmas of citizenship. Temple university press Philadelphia.

Pufedrof, S. (1991). On the duty of man and citizen according to natural law. Cambrdge University press.

Qari Sayed Fatemi, S. M. (2012). Human rights in the modern era, 1. Tehran, Shahre Danesh Institute of Law.

Seymour, M. L. (2005). The Encyclopedia of Democracy, 2. (Fani \& Moradi, Trans.). The Ministry of Foreign Affairs Publication.

Sharifi, T. K. H. (2014). An introduction toglobal citizenship. Tehran, Mizan Publication.

Sharifi, T. K. H. (2014). Citizenship rights. Tehran, Mizan Publication.

Weiissbrodt, D., \& Meili, S. (2010). Humanrights and protection of non citizens: Whither universality and $\begin{array}{llllll}\text { indivisibility of rights. Refuge survey quarterly, } 4, & 20 .\end{array}$ http://unchroncile.un.org/article/international-human-rightslaw-short-history 2august2015

\section{Note}

Note. Human rights committee, generalcommet 15 on the positios of aliens under the convenant, 11 April 1986.

\section{Copyrights}

Copyright for this article is retained by the author(s), with first publication rights granted to the journal.

This is an open-access article distributed under the terms and conditions of the Creative Commons Attribution license (http://creativecommons.org/licenses/by/3.0/). 